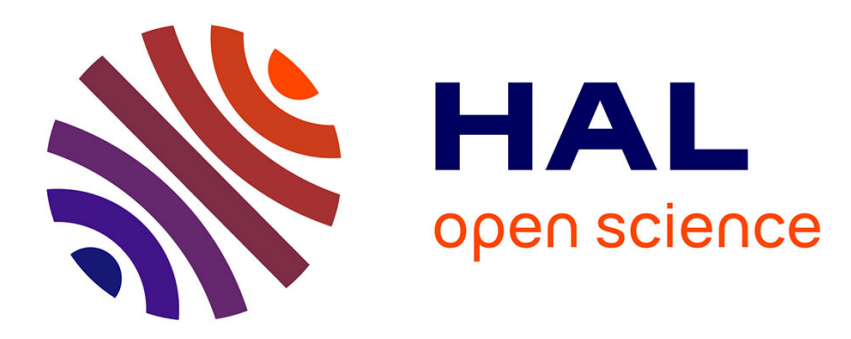

\title{
Heinrich Nissen and the Orientation of the Templum
} Amelia Carolina Sparavigna

\section{To cite this version:}

Amelia Carolina Sparavigna. Heinrich Nissen and the Orientation of the Templum. 2021. hal$03221145 \mathrm{v} 2$

\section{HAL Id: hal-03221145 \\ https://hal.science/hal-03221145v2}

Preprint submitted on 11 May 2021

HAL is a multi-disciplinary open access archive for the deposit and dissemination of scientific research documents, whether they are published or not. The documents may come from teaching and research institutions in France or abroad, or from public or private research centers.
L'archive ouverte pluridisciplinaire HAL, est destinée au dépôt et à la diffusion de documents scientifiques de niveau recherche, publiés ou non, émanant des établissements d'enseignement et de recherche français ou étrangers, des laboratoires publics ou privés. 


\title{
Heinrich Nissen and the Orientation of the Templum
}

\author{
Amelia Carolina Sparavigna \\ Dipartimento di Scienza Applicata e Tecnologia \\ Politecnico di Torino
}

\begin{abstract}
Of Heinrich Nissen, Clive Ruggles tells that he "deserves more than anyone else to be recognized as the earliest pioneer of modern archaeoastronomy". In fact, the German professor of ancient history studied the orientations of Egyptian and Greek temples and the orientations of churches too. However, Nissen is rarely mentioned in accounts of the early development of ideas and methods for archaeoastronomy. The aim of my contribution is to remedy the fact that Heinrich Nissen is not given due consideration and properly appreciated. I discuss in particular his Das Templum, where we can find his thought that the decumani of the towns were oriented to sunrise on the foundation

day. He proposed to compare sunrise and decumanus azimuths to find this day. Moreover he linked it to Roman festivals. Some literature, where Nissen's thought has been discussed in the past, is also given.
\end{abstract}

Torino, May 9, 2021

\section{The professor of ancient history}

Heinrich Nissen was a German professor of ancient history ${ }^{1}$. He studied in Kiel under Karl Wilhelm Nitzsch and in Berlin under August Boeckh and Theodor Mommsen. After graduating, he travelled in Italy between 1863 and 1867. This research was later published as his Italischen Landeskunde (1883 and 1902). In 1869 he became associate professor in Marburg, and in 1870 full professor. In 1877 he relocated to the University of Göttingen as a professor of ancient history, and soon afterwards, served as a professor at Strasbourg. In 1884, he moved in Bonn and there he taught ancient history. He also pioneered epigraphic researches at Bonn, based upon his studies during the years spent in Italy, and worked on Roman provincial archaeology. For his analyses of

1 https://en.wikipedia.org/wiki/Heinrich_Nissen see please references therein . In the foreword of "Archaeoastronomy in the Roman World", Magli, G., González-García, A.C., Belmonte Aviles, J., Antonello, E. (Eds.) 2019, (https://link.springer.com/content/pdf/bfm\%3A978-3-319-970073\%2F1.pdf) it is told that "While such important physicists as Heinrich Nissen and Norman Lockyer (active in the late nineteenth and early twentieth centuries) ... ". Lockyer was professor of astronomical physics, Nissen was professor of ancient history. 
the orientations of ancient sites with respect to sunrise, Nissen is considered by Clive Ruggles among the pioneers of archaeoastronomy. Nissen retired in autumn 1911.

Among his works we find Kritische Untersuchungen über die Quellen der vierten und fünften Dekade des Livius, 1863, Griechische und Römische metrologie, 1866, Pompeji, Lüderitz, Berlin 1867, Das Templum, antiquarische Untersuchungen, mit astronomische Hülfstafeln von B. Tiele. Weidmannsche Buchhandlung, Berlin, 1869, Pompeianische Studien. Leipzig 1877, Italische Landeskunde: Bd. 1 Land und Leute, Berlin 1883; Bd. 2: Die Städte (2 Teilbände), Berlin 1902, Orientation, Studien zur Geschichte der Religion, 3 v. in 1, Berlin: Weidmann, 1906-1910.

\section{The orientation of decumani}

Chapter VI of Das Templum by Nissen is devoted to the orientation according to sunrise. The Latin templum is the Greek temenos. It is a piece of land marked off from common uses and dedicated to a god, a sanctuary, holy grove or holy precinct. Besides to temples, Nissen applied his theory of the templum to the layout of Roman colonies too. In this manner, he proposed an orientation of the Decumanus, one of the two main axes of Roman settlements ${ }^{2}$, according to sunrise on the foundation day of the colony. He also told that this day was corresponding to a Roman festival. He gives Brindisi as an example. We know that the foundation day, Dies Natalis, of Brundisium was August 5, Nones of Sextilis, Festival of Salus, from two Cicero's writings.

For what concerns the orientation to sunrise, this orientation is mentioned among those reported by the Roman surveyors (gromatici) (see Libertini). We find the orientation "secundum coelum", that is according to North-South and East-West directions, the orientation according to the wide range of land, according to coastlines or mountain ranges, or along main roads (see Le Gall). Latin literature is also telling that only inexperienced surveyors were using the direction of sunrise, which is changing during the year, instead of the proper one, the East-West direction, which is fixed. Moreover, let us stress that no Latin source is mentioning that the Roman colonies were founded on festivals. No mention exists. We know that the Romans commemorated the foundation by a festival, but this does not mean that the festival itself had to be coincident with the day when "lineamenta", the lines marking the land, were established by colonial commissioners and surveyors.

The foundation of a colony was a long sequence of works starting from the surveying of the area chosen for its location and ending with the exhibition of the "forma urbis" (a map) in the forum, accompanied by the Lex Colonica (the map caption). In this long sequence of actions and days, what was the one that colonists commemorated? Different opinions exist (see Eckstein). This is due to the fact that no Latin source is mentioning what was the specific day commemorated by colonists as Dies Natalis. No Latin source, no one.

2 The other axis is known as Cardo. 
As previously told, Nissen's direction of decumanus, coincident to a sunrise azimuth, and the link to Roman festivals are given in Chapter VI of Das Templum. The "Nissenschen Theorie" is also reported by Friedrich Nietzsche in his lessons about Der Gottesdienst der Griechen. Here in the following it is reported what Nissen is telling.

"Diese Erklärung, welche sich aus den Worten der Gromatiker mit Notwendigkeit ergiebt, eröffnet eine ganz neue Betrachtungsweise. Wie jeder Mensch, so hat auch der Gott und die Götterwohnung und das Templum in seinen verschiedenen Anwendungen überhaupt einen Geburtstag. Dies gilt ebenso von der Stadt: einige Geburtsjahre italischer Städte sind S. 56 zusammengestellt. So wenig wir hiervon wissen, erscheint unsere Kunde bezüglich der Geburtstage doch noch weit dürftiger. Für Rom wird er bezeichnet durch das Parilienfest am 21. April, für die Colonic Brundisium durch das Fest der Salus auf dem Quirinal am 5. August. Nach dem oben Gesagten muss also die Richtung des Decumanus entsprechen dem Sonnenaufgang am Gründungstag des Templum. Und um die Theorie auf gegebene Fälle anzuwenden, lässt sich aus dem Decumanus der Gründungstag finden, oder falls der Tag bekannt, die Richtung des Decumanus".

In the first part of the Chapter, Nissen is proposing selected well-known sentences from the Roman surveyors' literature in Latin (for any supporter of the decumanus orientation to sunrise it is enough to copy and past them, and translate from German the related discussions). Heinrich Nissen claims that he has explained the meaning of the given sentences. The text in German tells that this explanation, which necessarily follows from the words of gromatici, opens up an entirely new way of looking at these things. Like every human being, a god or a god's dwelling place - or the Templum in its various applications - has a birthday in general. This also applies to the town: some years of birth of Italian towns are given S. 56. Little we know about years then, and our sources seem even poorer when it comes to birthdays. For Rome it is designated by the festival of Parilie on April 21st, for the Colony Brundisium, by the festival of Salus on the Quirinal on August 5th. According to the discussion above, the direction of the decumanus must correspond to the sunrise on the day the Templum was founded. And to apply the theory to given cases, the founding day can be found in the Decumanus, or if we know the day, the direction of the Decumanus is given.

\section{De Petra's review and Castagnoli - Catalano observations}

Nissen's conclusions are coming from his interpretation of the literature of Roman surveyors and of Roman mythology. His approach had a consequence: the birthday of a colony, Dies Natalis, was associated with the day when the direction of its decumanus was determined, but this is not true (see discussions Eckstein and Conventi). Moreover, as evidenced by Giulio De Petra in his review of Das Templum, Nissen was choosing only those passages useful for his ideas and avoided to consider other evidences, which were not in agreement with his theory. 
For the astronomical references in town foundation, let us stress that the Latin sources consist in a few passages in the literature of Roman surveyors. Actually, this literature is concerning the subdivision of the land (centuriation) and is not specifically referring to the town foundation, as observed by F. Haverfield.

De Petra's review should be read carefully, to acknowledge all the criticisms to weak points in Nissen's work. Regarding the orientation of decumani, sunrise and festivals, De Petra stressed the problem of chronology too, that is, even if we are considering Nissen's assumptions as reasonable, it is not clear how they can be useful in a practical manner, due to the difficulty of manage chronological problems. The Roman calendar, before the reform made by Julius Caesar, was a lunisolar calendar. Civil days, those given by the lunisolar calendar, were all like our Easter Day and had a corresponding sunrise azimuth changing cyclically year by year, as in the case of Easter Day indeed. Therefore, Kalends, Nones, Ides and other festivals, did not possess an unequivocally defined sunrise azimuth. Let us also add that the lunisolar Roman calendar was often irregularly managed and this is the reason of the Julian reform of it, to have a calendar corresponding regularly to the apparent motion of the sun. Studies concerning Brindisi and Bononia, whose Dies Natalis are known, were made by me to evidence the problem of chronology ${ }^{3}$.

As previously told, De Petra discussed in detail Das Templum. In my discussion in Italian of the Nissenschen theorie, other concerns raised by several scholars have been mentioned. It is told: Sul fatto che la città fosse un templum ne scrive Ferdinando Castagnoli [che] dice che l'ipotesi di Nissen "è stata giustamente contraddetta dal Valeton e dal Thulin". Infatti, vi sarebbe anche da discutere quale fosse il rito etrusco usato da Nissen, che tuttavia riteneva rito italico. In [Catalano] si dice che è necessario sottolineare come dalle fonti antiche non risulti che l'Etruscus ritus esigesse, per l'inaugurazione del pomerium, una limitazione secondo decumano e cardine. Contro un errore persistente tra gli studiosi di antichità, nonostante i risultati raggiunti da Valeton (1892, De ratione decumani et cardinis diversa a ratione templorum terrestrium et aliena a reliquis templis), si è espresso Staccioli. Per ritenere che la limitazione secondo decumano e cardine fosse parte essenziale del rito etrusco di fondazione delle urbes, si può trovare appiglio solo nei passi relativi alla cosiddetta Roma quadrata, quella di Romolo sul Palatino. In [Catalano] si dice però che il significato di quadratus nel termine Roma quadrata è discusso: per alcuni "quadrato", per altri "quadripartito", ossia

3 In 2007, an article written by Giulio Magli on the astronomical orientation of a set of Roman towns appeared in arXiv (arXiv:physics/0703213). The analysed towns have been chosen among the Roman towns in Italy. The aim of Magli's article was that of investigating a possible orientation of the main axis of the towns, the decumanus, according to the sunrise on a given day of the year, linked to Roman festivals, in the framework of a ritual inherited by Romans from Etruscans (Disciplina Etrusca). Given examples of Dies Natalis are Rome and Bononia (Bologna). Therefore, in 2007, the sunrise orientation and the link to Roman festivals appeared again. Magli is not mentioning the Nissen's theory of the orientation of decumani. The Nissen's Templum in not among references. In some of my previous studies about solar orientation of Roman towns I was referring to Magli's work. 
diviso in quattro parti. "Comunque, anche ammesso che la concezione della città primitiva come quadrata (con riferimento al decumanus ed al cardo) fosse tradizionale, non se ne potrebbe ricavare che secondo le fonti la limitazione in base a decumanus e cardo fosse parte necessaria del rito etrusco di fondazione" [Catalano] e ivi si citano, come in Castagnoli, Valeton e Thulin. "Altro è, ovviamente, che la limitatio secondo decumanus e cardo fosse considerata dai Romani di origine etrusca".

Ferdinando Castagnoli writes about the fact that the town was a templum in his book, where he says that Nissen's hypothesis has been rightly contradicted by Valeton and Thulin. In fact, it would also be debatable what was the Etruscan rite used by Nissen, who believed it was an Italic traditional rite. In [Catalano] it is said that it is necessary to emphasize the fact that, from the ancient sources, it does not appear that the Etruscan ritus required, for the inauguration of the pomerium, a limitation according to decumanus and cardo. Against a persistent error among scholars of antiquity, despite the results achieved by Valeton (1892, De ratione decumani et cardinis diversa a ratione templorum terrestrium et aliena a reliquis templis), Staccioli expressed himself too. To believe that the limitation according to decumanus and cardo was an essential part of the Etruscan rite of foundation of the towns, we can find only a few passages referring to the so-called Roma quadrata, the Rome of Romulus on Palatine Hill. However, in [Catalano], it is said that the meaning of "quadratus" in the "Roma quadrata" is discussed: for some people, it means "square", for others "quadripartite", i.e. divided into four parts. "Anyway, even assuming that the conception of the primitive town as a square (with reference to decumanus and cardo) were traditional, we cannot deduce that, according to the sources, the limitation on the basis of decumanus and cardo were a necessary part of the Etruscan rite of foundation" [Catalano] and therein we find cited the same, as in Castagnoli, Valeton and Thulin. "Different, of course, is the conception that the limitatio according to decumanus and cardo was considered by Romans to be of Etruscan origin".

\section{The discussion by Erdmann}

The theory by Nissen was also discussed in detail by Martin Erdmann. He is telling the following. In ein ganz anderes Gebiet rückt die Frage nach den griechischen Städteanlagen, wenn wir von der Nissenschen Theorie ausgehen . Nissen hat nämlich für die italische auf den beiden sich kreuzenden Linien Kardo und Decumanus basierende Limitation das Gesetz eruiert, dass die Richtung des Decumanus dem Sonnenaufgangs- oder Untergangspunkt am Gründungstage des Templum, das heißt des mit religiöser Weihe vermessenen Raumes für Lager, Stadt und Tempel entspricht . Jener Gründungstag ist der Geburtstag des Templum ; denn wie jeder Mensch, so hat auch der Gott und die Götterwohnung und das Templum in seinen verschiedenen Anwendungen überhaupt einen Geburtstag. Daraus folgt, dass wir aus den Ruinen einer Stadt oder eines Tempels den Gründungstag, der dann für den Tempel zugleich der Geburts- oder Festtag des darin verehrten Gottes ist, entnehmen können . Man sucht 
nämlich die Hauptstraße der Stadt, beziehentlich die Längenachse des Tempels, misst die Abweichung dieser Linie von der genauen Ostwestlinie in Graden, und berechnet alsdann astronomisch -- nach den dem Templum beigegebenen Tieleschen Tabellen das Monats datum, an welchem die Sonne im Gründungsjahr mit dieser Entfernung vom Ostpunkte auf oder unterging. Umgekehrt kann man, wenn der Gründungstag, oder bei einem Tempel der Festtag des Gottes, dem er gehörte, bekannt ist, die Lage der Hauptstraße oder Tempel achse berechnen .

In Nissen's theory, the question of Greek urban planning moves to a completely different area. Namely, for the Italian limitation based on the two lines Kardo and Decumanus, Nissen explained his law which says that the direction of Decumanus corresponds to the sunrise or sunset point of the day the Templum was founded, i.e. the space for a military camp, a town or a temple, was measured by the corresponding religious consecration. The foundation day is the birthday of the Templum, because like every human being, divinity and god's dwelling place, the Templum in its various applications has a birthday. From this it follows that from the ruins of a town or a temple we can deduce its foundation day, which for a temple is also the birthday or feast of the god worshipped therein. We look for the main street of a town or the longitudinal axis of a temple, we measure the deviation of this line from the exact east-west line in degrees, then we calculate astronomically - according to attached tables [in Das Templum] - the date of the month in which we find the sun to rise with that azimuth. Conversely, if you know the foundation day or, in the case of a temple, the feast of the god to which it belonged, you can calculate the location of the main road or axis of the temple.

Erdmann continues with Italian temples. Nissen himself distinguishes three classes, the first of which includes those temples whose longitudinal axis is in direct relation to the sun in the way previously indicated; in the second class we find the temples with axis from north to south, and the transverse axis directed towards sunrise or sunset [equinoctial]; and in the third we can find the temples where both directions have no relationship with the sun. With one exception, the Temple of Apollo in Phigalia, the Greek temples preserved up to the present day are all facing east, that is, in such a way that front entrance and face of the cult idol were facing the dawn and the morning sun filtering through the door. The most precise direction oscillates between 248 and 298 degrees, with the east taken equal to 270 degrees. But all points lie within the boundaries of sunrise that apply to those regions (latitudes). However, Nissen immediately concludes that the law applies not only to Greek temples, but much more generally to Italian temples too.

That is, Erdmann is stressing that Nissen is applying what he deduced from Greek temples to the Italian temples. Are we sure that this is possible? In any case, the orientation of temples and settlements is an important question. 
Die Frage ist eine der interessantesten der Topographie und bedarf weiterer Aufklärung . Für Italien hat Wolfgang Helbig einen sehr schätzbaren Beitrag geliefert, indem er diese Rücksichtnahme auf den wirklichen Aufgangspunkt der Sonne, nicht den genauen. Ostpunkt, schon bei den vielen jetzt untersuchten Pfahlbauten des Po landes aufgefunden hat. Die Niederlassungen, sagt Helbig, bilden Oblonge, deren Schenkel nach den vier Himmelsgegenden orientiert sind. Doch ist die Orientierung, abgesehen von einem Falle, keine astronomisch genaue, scheint vielmehr in empirischer Weise nach Punkten bestimmt, wo die Sonne während des Frühjahrs aufund untergeht. Jener eine Fall geht auf die terramare - so nennt man die Stellen der Pfahlbauten - von Montecchio . Hier liegen drei Pfahl bauten über einander . Während die beiden untern in der gewöhnlichen empirischen Weise orientiert sind, entspricht die Anlage der obersten genau dem Meridian . Und auch dies kommt, wie Helbig selbst sagt, vielleicht daher, dass die Anlage zur Zeit der Tag- und Nachtgleiche erfolgte . Für Griechenland wird die Forschung durch den griechischen Kalender bedeutend erschwert, der mit seinen Mondmonaten und umständlichen Schaltungen der Umrechnung in julianische Daten sich sehr widersetzt. Nichtsdestoweniger muss einmal untersucht werden, ob und inwieweit die Nissensche Regel auch für die griechischen Städteanlagen gilt : eine Frage, die noch ganz offen ist .

The question is one of the most interesting in topography and needs further clarification. For Italy, Wolfgang Helbig has made a very valuable contribution, as this Nissen's hypothesis has been verified to be relative to the true point of sunrise, and not to the exact one [equinoctial], by studying the many stilt-house settlements in the Po valley that have been examined. Helbig says that oblong partitions of the ground were formed, oriented towards the four regions of the sky. However, apart from one case, the orientation is not astronomically exact, rather it seems empirically determined by the points where the sun rises and sets during the spring. There is an interesting case of terramare - this is the name of the places with stilt houses - and it is that of Montecchio. Here are three stilt house dispositions, one above the other. While the two older are oriented in the usual empirical way, the arrangement of the upper one corresponds exactly to the meridian. And this too, as Helbig himself says, could be due to the fact that the housing system was placed at the time of the equinox. For Greece, the search is made significantly more difficult by the Greek calendar, which, with its lunar months and relevant changes, is very resistant to conversion to Julian dates. However, it is necessary to examine whether and to what extent the Nissen rule also applies to Greek urban systems: the question is still completely open.

\section{From the Philologischer Anzeiger}

In the Philologischer Anzeiger we can find a critical review of Nissen's theory, a theory that discerns a templum everywhere. It is also recalled that Nissen does not consider Varro's words on the Templum (in heavens, terrestrial and subterranean) in an appropriate manner. Nissen discards the subterranean one, because he says it is from 
Hellenics and not from Italics. But at least one subterranean templum existed in Rome. Other well-documented criticisms also follow. At a certain point, speaking of the temples and the space (temenos) that surrounds them, the reviewer wonders: What is the given guarantee that the axis of the construction of the temple and not that of the entire auspicious temple consecrated to the divinity was oriented according to the augural theory? So, if we put a temple in a square, how do we deal with the relative plan? And then again, according to clear ancient evidence, the Romans had a division of the celestial templum into four parts, while the Etruscans made use of sixteen parts, and how can this difference be explained?

Let us see the ending of the review.

We are grateful for the material he [Nissen] provides, but we have to be cautious. For example, not all the worship places are Templa, Nissen says. Those that do not have the rectangular shape are not temples. However, we find Nissen himself who says that the Pantheon is a templum, but it is round! It can be seen that Nissen has crossed the line several times, and there could be many other things needing criticisms. But let us tell it again, the work contains such an abundance of ingenuity that it will certainly inspire those who wish to subject this whole important area of antiquity to renewed and indepth investigations. We would just like to express to them the hope that, first of all, the foundations of their investigation are assured by a more complete and critical compilation of the many ancient written sources that provide information in many, and often strange, pages on sacred disciplines. In particular, however, the theory of the templum seems to have to be applied with great attention to the layout of the town of Rome and to a historically verifiable expansions of its pomerium. What Nissen says in this regard (p. 85): "Der decumanus maximus der servianischen Stadt ist die sacra via, welche die beiden nördlichen regionen von der palatina und suburana trennt", "The decumanus maximum of the Servian town is the sacred road, which separates the two northern regions from the palatine and the suburana", we do not admit in any way as true due to the local, clearly existing, conditions.

\section{The archaeoastronomer}

Of Heinrich Nissen, Clive Ruggles tells that he "deserves more than anyone else to be recognized as the earliest pioneer of modern archaeoastronomy". He studied the orientations of Egyptian and Greek temples and also the orientations of churches, "where he was responsible for demolishing the popular myth that all churches faced (precisely) east. He was an almost exact contemporary of Sir Norman Lockyer in England, but he anticipated Lockyer's own measurements of Egyptian temples. Indeed, Lockyer was dismayed to discover the existence of Nissen's published work after returning from his own first season in Egypt and, when putting forward his own ideas that the temples were aligned upon the rising and setting of the sun and stars, fully acknowledged that Nissen had anticipated him in suggesting the possibility". 
Ruggles is also telling that "The fact that Nissen is rarely mentioned in accounts of the early development of ideas and methods in what subsequently became known as archaeoastronomy, whereas Sir Norman Lockyer is generally considered the earliest serious pioneer in the subject, is explained by the fact that initial developments in modern archaeoastronomy in the 1960s and 1970s primarily took place amongst English-speaking scholars".

Nissen's works have been published only in German. However, as we have seen, it has been discussed in details by many scholars, and in Italy too. Many concerns were raised not only about the solar orientation, but also about the link of Etruscan heavens to Roman quadripartite space, and in general about his theory of the templum. In spite of the fact that Nissen was well-known in the past, today we find him defined as "physicist", mentioned just in the foreword of a book based on a current revival of solar theories in Roman world.

Actually, the aim of my contribution is to remedy the fact that Heinrich Nissen is not given due consideration and properly appreciated. At the same time some literature, where Nissen's thought has been discussed, has been given too.

\section{References}

Conventi, M. (2004). Città romane di fondazione (No. 130). L'Erma di Bretschneider.

Ferdinando Castagnoli (1956). Ippodamo di Mileto e l'urbanistica a pianta ortogonale. De Luca.

Catalano, P. (1978). Aspetti spaziali del sistema giuridico- religioso romano. Mundus, templum, urbs, ager, Latium, Italia. In Aufstieg und Niedergang der Römischen Welt, Temporini H. und Haase W. Eds., De Gruyter.

De Petra, Giulio (1869). Recensione del Das Templum. Giornale degli Scavi di Pompei (nuova serie), Maggio-Giungo 1869, Napoli.

Eckstein, A. M. (1979). The Foundation Day of Roman" Coloniae". California Studies in Classical Antiquity, 12, 8.

Erdmann, M. (1883). Zur Kunde der hellenistischen Städtegründungen, Strassburg.

Haverfield, F. (1913). Ancient town-planning. Oxford, The Clarendon Press.

Le Gall J. (1975). Les romains et l'orientation solaire. MEFRA 1975-87-1, p. 287-320.

Libertini, G. (2018). Gromatici Veteres. Gli Antichi Agrimensori - Traduzione in 
Italiano con commenti, figure, schemi e illustrazioni a cura di Giacinto Libertini e con presentazione di Gianluca Soricelli. Istituto Di Studi Atellani, Frattamaggiore, Naples \& Copernican Editions

Nietzsche, F. (1875). Der Gottesdienst der Griechen. Gesammelte Werke, 1844-1900, archive.org (archive.org/details/gesammeltewerke05nietuoft/page/354/mode/2up).

Nissen, H. (1869). Das Templum, antiquarische Untersuchungen, mit astronomische Hülfstafeln von B. Tiele. Weidmannsche Buchhandlung, Berlin.

Philologischer anzeiger: Als ergänzung des Philologus, Band 2. Jan 1870. Dieterichsche buchhandlung. Pag.117

Ruggles, C. L. N. (2005). Ancient Astronomy: An Encyclopedia of Cosmologies and Myth, ABC-CLIO.

Sparavigna, Amelia Carolina, What the Latin Literature Truly Tells Us About the Orientation of Camps, Towns and Centuriation (August 6, 2020). Available at SSRN: https://ssrn.com/abstract=3675354 or http://dx.doi.org/10.2139/ssrn.3675354

Sparavigna, Amelia Carolina. (2020, November 8). L'archeoastronomia e la Nissenschen Theorie, ovvero quanto disse Heinrich Nissen sull'orientazione solare del Templum. Zenodo. http://doi.org/10.5281/zenodo.4439304

Sparavigna, Amelia Carolina. (2020, November 2). Brindisi e il suo giorno natale, tra cronologia ed astronomia. Zenodo. http://doi.org/10.5281/zenodo.4190161

Sparavigna, Amelia Carolina, Bononia, the Roman Bologna: Archaeoastronomy and Chronology (November 2, 2020). Available at SSRN: ttps://ssrn.com/abstract=3421339 or http://dx.doi.org/10.2139/ssrn.3421339

Staccioli, R. A. (1968). Urbanistica etrusca, Archeologia Classica 20, 141.

Thulin, C. O. (1906). Die etruskische Disciplin.Die Etruskische Disciplin V1-2: Die Blitzlehre Und Die Haruspicin, Nuova Edizione. Kessinger Publishing, LLC (April 18, 2010)

Valeton, I. M. J. (1892). De templis romanis. Mnemosyne, 338-390; Valeton, I. M. J. (1893). De templis Romanis (Continued). Mnemosyne, 62-440. 


\section{Das Himmelstemplum.}

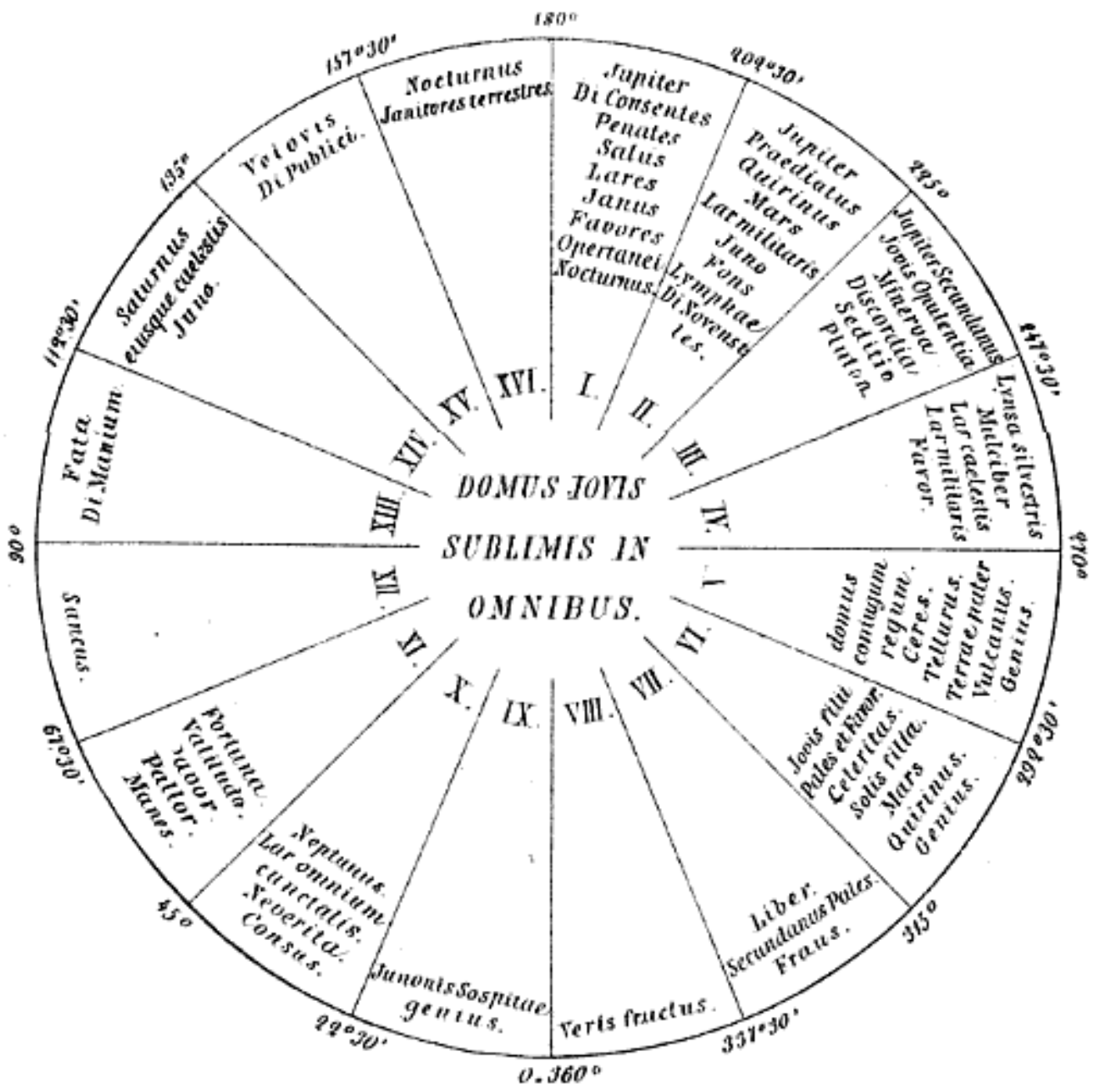

Fig. 1 - The Templum in the heavens by Nissen. 


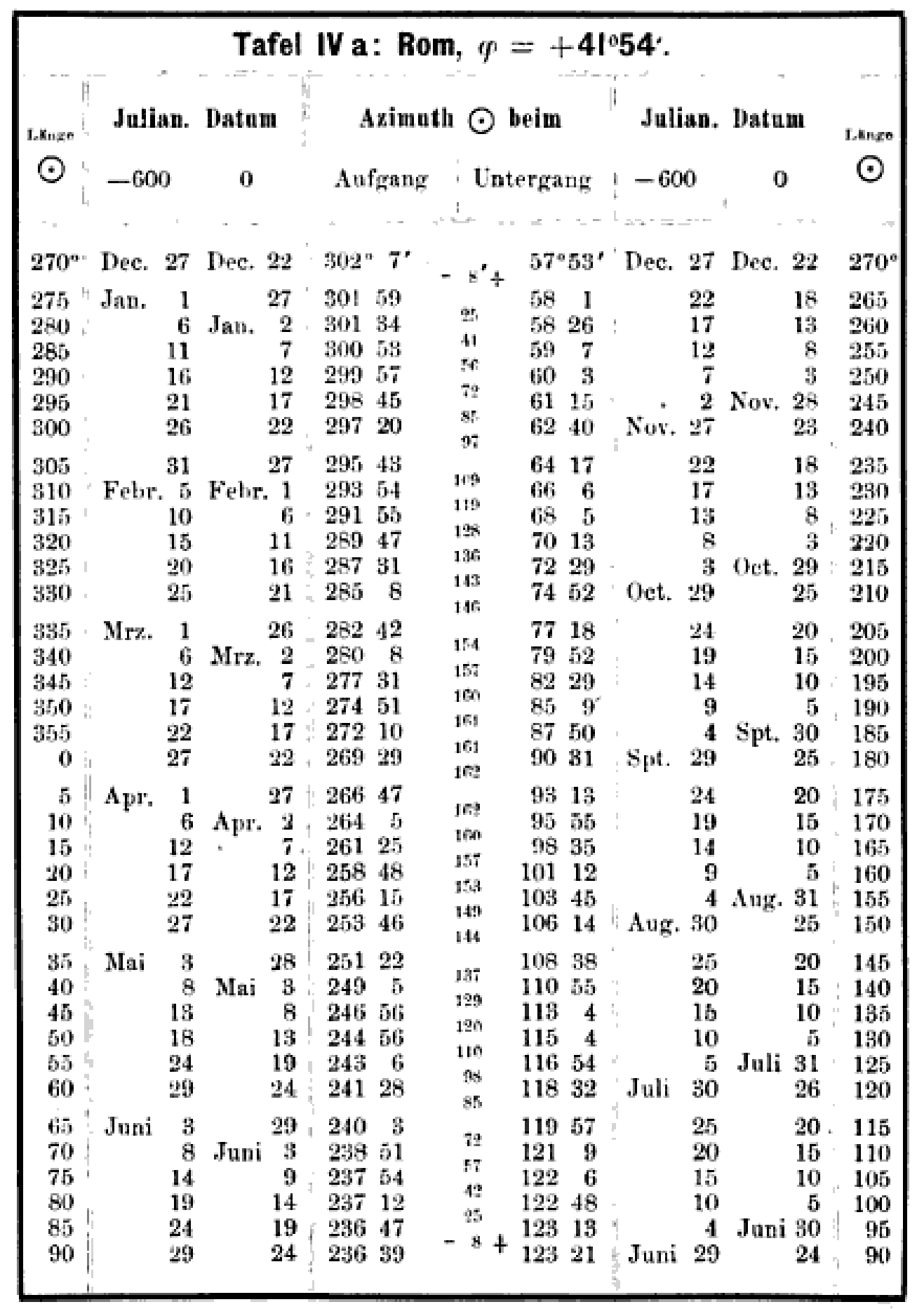

Fig.2 - A table from Das Templum 